\title{
Problems and Solutions in Revitalizing Endangered Tribe Community in Minangkabau Culture
}

\author{
Irwan Malin Basa \\ Cultural Preservationist and Senior Lecturer of State Institute of Islamic Studies Batusangkar, \\ West Sumatera, Indonesia
}

\begin{abstract}
This study discusses about problems and solutions in revitalizing endangered tribe community in Minangkabau, West Sumatera, Indonesia. One of the endangered tribe communities in Pariangan is called Pidang Laweh tribe. This community has only one family which belongs to its member. Revitalization is needed to protect their life, culture, traditional house and the way of how they apply and respect their culture. All about the needs for their sustainable culture preservation should be provided by the local government to make them able to have the same degree with other communities. The purpose of revitalization is to empower their critical endangered life to be a better life. Through this research there were many problems faced such as misunderstanding of the program of revitalization, difficulties in gathering the material for traditional house, lack of paying attention to the future life, the influence of the modern life to traditional culture and the difference of perception about modern life. There are some solutions proposed to protect and to save them such as giving the wider access for the tribe members, financial support, educational and economic priority and to make them more aware of the culture itself.
\end{abstract}

Key Words: Endangered tribe, Minangkabau culture, revitalization, traditional house, rumah gadang

\section{INTRODUCTION}

In West Sumatera, the oldest village ever built by the ancestors is called Pariangan. The meaning of Pariangan is "a very happy place", but some people understand the meaning of Pariangan as "a village of God". The first kingdom in Pariangan is called Pasumayan Koto Batu. The civilization of Minangkabau had begun since this era. From this village the culture then developed into many areas around West Sumatera. Pariangan is also known as the source of adat in West Sumatera.

In Pariangan there are eight tribes community live together but one of them is in endangered condition because the members of the tribe is consisted of only one family. The tribe is called Pidang Laweh. Years ago, this tribe had seven sub tribes or clan. Without any specific reasons they have finally disappeared. The tribe community live in a very traditional way. For example, they have a traditional house which often called rumah adat for living. But now the condition of rumah adat is not good anymore. Then, they still go to rice field every day for food.. They live in a very simple way. They still respect each other.

Furthermore, this tribe also has a good principle for life which is called gotong royong. The meaning of gotong royong is working together for helping other people without any payment. Whenever they have a party in this village for example, many people from other tribe communities will come to help them. They help their neighbors each other, their villagers and their "brother" without any negotiation. But nowadays, the simple way of their life and the perception of the tribe about the traditional and modern life is much different.

Until now Minangkabau people is known all over the world for its unique heritage. Many researches have been conducted to study about this culture. Some researchers found a very interesting phenomenon about this culture but some did not. The very interesting phenomena is a traditional house and the principle of gotong royong. But both of them have also decreased and it is predicted that they will disappear step by step if there is no revitalization program from the government. Revitalization is a must for saving the culture.

As a cultural reservationist, I have done revitalization for this tribe community for six months. There were many problems faced in revitalizing the endangered tribe community but all of the problems should be solved as well possible to save the endangered community in the world. If it is not, when a community died or disappeared, no body of us able to make them alive again. This research mainly focused on revitalization of rumah gadang.

\section{THEORETICAL REVIEW}

The study of rumah gadang has been conducted by several previous researchers. Each of them has different point of view in concluding the research. Franzia, Piliang and Saidi (2015) focused their research on rumah gadang as a symbolic representation of Minangkabau ethnic identity. They told that rumah gadang, the 
traditional house of Minangkabau, is one of the symbolic representationof Minangkabau's identity. They cited Pierce's theory of semiotics, rumah gadang is becoming the icon of Minangkabau's ethnic group and becoming their ethnic identity. Based on the theory above, it can be concluded that every tribe in Minangkabau must have rumah gadang for their identity. It can be said that any tribes which does not have any rumah gadang has no identity!

The function of rumah gadang is not only a place for living but also for family gathering, for family meeting, wedding party and also for saving the properties of the community. When there was a party in rumah gadang for example, many family will come to visit it. Moreover, the structure, form, size, position and style of rumah gadang is also different from one to another. On the other hand, rumah gadang also reflects the culture and the values of each community.

In Pariangan there are thirty three rumah gadangs until now but not all of them in healthy and ready to be occupied. For that reason the broken one should be revitalized as well as possible to preserve cultural existence. But to revitalize a rumah gadang needs much money while the community live in a poor condition. This is a dilemma. Several programs have been done to preserve rumah gadang by the local government but the result have not been satisfactory yet.

Then, Hezel (2005) argued the related theory about the culture. In older anthropology textbooks, culture was identified with the products that a particular society produced: not just material artifacts (food and clothing and house styles), but also institutions, (village authority system, land inheritance patterns), beliefs (for instance, that sickness is the work of spirits), concepts (the particular view of the universe that people hold), values (like the importance of sharing, or disdain for boasting), and a guideline for behavior (such as funning flies for a guest at a meal, or keeping the eyes lowered when speaking to someone of higher status.

The cultural concept of the endangered tribe community is still hold by the community. They do understand about the culture so that they are reluctant to revitalizing their rumah gadang. They used to think traditionally but finally they can understand the meaning of revitalization after having a hot discussion between cultural preservationist and community members.

Furthermore, in revitalizing the community or rebuilding an old city or an old object there must be many problems to be encountered. Partain (2013) listed several problems in revitalizing a church, they are: (1) conflict of a different kind. (2) Problems of a different kind. (3) Healthy process of making big decision. (4) A focus on knowing and doing the Bible. (5) Disciple-making process. (6) Financial decisions aligning with strategy decisions. (7) Stability and integrity in senior leadership. (8) A high level of appreciation for pastoral leaders. (9) An Acts 1:8 strategy for mission. And (10) Simplification of structure.

\section{METHODOLOGY}

In this research Community Based Participatory Action Research (CBPAR) was carried out to do revitalization. As stated by Janice C, Burns (2011) CBPAR is a collaborative approach to research that involves all stakeholders throughout the research process, from establishing research question, to developing data collection tools, to analysis and dissemination of findings. There were several steps which have been applied to revitalize rumah gadang in preserving endangered tribe community, they are:

1. Identify research topic, questions, goal, and geographic focus

1.1. What is to be revitalized?

1.2. Why should it be revitalized?

1.3. What is the revitalization for?

1.4. Where is revitalization conducted?

1.5. How is revitalization conducted?

2. Identify research partners and invite them to collaborate

2.1. Who will be involved in this revitalization?

2.2. Involving every stakeholders

2.3. Endangered tribe community

2.4. Local government

3. Choose and implement the research and data collection methodology

3.1. Doing revitalization

3.2. Note taking

3.3. Documentation

4. Analyze the results

4.1. Analyzing revitalization results

4.2. Discussion 
4.3. Revision

4.4. Quality

5. Report the research results

5.1. Reporting all process in revitalization

\section{DISCUSSION}

\section{Problem of the difference of perception about revitalization}

In revitalizing rumah gadang there were many problems found by the researcher. The first problem is the difference of perception about the revitalization itself. Before revitalizing rumah gadang the members of the tribe community were invited to discuss about the program. The preservationist tried to share with them about the program. Many questions have been asked to make a deal but not all of the programs to be agreed. Some of the tribe members did not agree with the planning (work plan) which have been made. They assumed that revitalization program will change the structure of rumah gadang so that it will be in a new model. The members of the tribe were very afraid of the changing of rumah gadang for examples: the structure of rumah gadang, function of rumah gadang, the orientation of rumah gadang and even the ownership of rumah gadang. They though that rumah gadang will be occupied by the government after the revitalization. They assumed that they will have a very limited access for their own house later after revitalization. It was very hard to convince them because they have low education, lack of economic access, lack of information from the government about the development of the world today.

\section{Problem of making decision}

The next problem is the problem of decision making. Before conducting revitalization the researcher must have a certain decision from the head of the tribe. When it is not allowed by him nobody may do the work. The difficulties of making decision sometimes influenced by the pro and contra people in the tribe. In Minangkabau people have a collegial leadership. If one of the tribe members disagree about the program so that the program will be postponed or might be cancelled. The decision must be agreed by all tribe members. Minangkabau people do not apply the concept of voting in making decision but they apply musyawarah mufakat (discusiion among all members. Each of them must agree or disagree about the decision).

\section{Problem of the lack of material}

Then, the problems of the lack of material for rumah gadang. Nowadays, not all of the material for building rumah gadang available in the closest area of the community. It might cause by the illegal logging and the regulation from the government which really prohibited people to cut the specific trees in specific location. This is a serious and a big problem for the community in their life. The high demand of the best quality materials also caused by the disappearance of the high quality material like specific woods, bamboo, coconut trees, palm fiber, rattan and other related materials. The cost of material also increases every year.

\section{Problem of workers, architecture and expert}

Beside the three problems above, the problem of workers and architecture may not be ignored. To build rumah gadang needs many skillful workers and at least one experienced traditional creature or architecture. Nowadays, it is very difficult to find them. It was caused by the difficulties of specific work in building rumah gadang like wood curving, making the unique roof, balancing each side and value of each part of the building, and deciding where to begin first. For workers, they should work without any payment. They should work socially to help their neighbor in revitalizing rumah gadang. Not many social workers wanted to come helping revitalization program. They want to get money from their works. Untill now there is no schools or universities have the specific subject about rumah gadang studies and design. A high motivated person who will concern on rumah gadang building must study it informally with the experienced creature of rumah gadang.

\section{Problem of local government and any related institution}

The problem of local government supports and any related offices sometimes forbid the implementation of the revitalization concept. It was caused by the different orientation between government and the community. To revitalize a community needs many recommendation letters or the legalization from the government. It was caused by the former government staff have registered some rumah gadangs to UNESCO for world heritage program. When a rumah gadang has been registered in UNESCO the process of revitalization will be difficult because we must have a written permittion to revitalize it.

\section{Financial problem}

The next big problem is financial problem. Every things in modern life needs money. Without having much money the program of revitalization will not run well. Many manufactured products like paint, nails, zinc and many others also also used in building rumah gadang so that for obtaining the products need money. Beside the manufactured products there are kinds of row materials like sand, stones, coral and palm fiber that should be ordered. The cost of the material always increase every year. It is never getting low cost. 


\section{Problem of originality}

At the end of revitalization there must be a tight quality control for the result of revitalization work. There may not be used materials or low quality materials to be used for building rumah gadang. Its purpose is to keep the originality of the structure of rumah gadang. To guaranty this originality an expert of rumah gadang should scrutinize all the works seriously. When it is found a bad quality of the job the workers must redo the works again. It will take much times to finish and it needs more extra money of course.

Below the table of problems and alternative solutions in revitalizing rimah gadang in Minangkabau:

Table 1. Problems and alternative solutions in revitalizing rumah gadang

\begin{tabular}{|c|c|c|}
\hline Kinds of Problems & Alternative solutions & Recommendation \\
\hline $\begin{array}{l}\text { - Different } \\
\text { perception of the concept of } \\
\text { revitalization }\end{array}$ & $\begin{array}{l}\text { Conducting focus group } \\
\text { discussion; talking and sharing } \\
\text { about revitalization }\end{array}$ & $\begin{array}{l}\text { - Involving } \\
\text { stakeholders }\end{array}$ \\
\hline $\begin{array}{l}\text { - Problem of making } \\
\text { decision }\end{array}$ & $\begin{array}{l}\text { Getting a valid decision } \\
\text { from the head of the community }\end{array}$ & $\begin{array}{l}\text { - No more argument } \\
\text { after decision making }\end{array}$ \\
\hline $\begin{array}{l}\text { - Problem of material } \\
\text { for rumah gadang }\end{array}$ & $\begin{array}{l}\text { Collecting all materials } \\
\text { before conducting revitalization }\end{array}$ & $\begin{array}{l}\text { - Write a complete list of } \\
\text { the materials needed }\end{array}$ \\
\hline $\begin{array}{l}\text { - Problem of workers } \\
\text { and architecture }\end{array}$ & $\begin{array}{l}\text { - invite workers and } \\
\text { architecture and expert }\end{array}$ & $\begin{array}{l}-\quad \text { to make sure all } \\
\text { workers, architecture and expert } \\
\text { to get ready to work }\end{array}$ \\
\hline 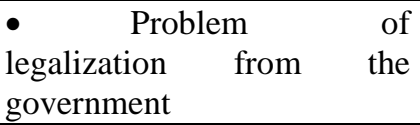 & $\begin{array}{l}\text { - Proposing all related } \\
\text { documents of legalization to } \\
\text { government and related institution }\end{array}$ & $\begin{array}{l}\text { - } \quad \text { Communicate } \\
\text { program to all related office }\end{array}$ \\
\hline - $\quad$ Financial problem & $\begin{array}{lll}\text { - } & \text { Looking for funding or } \\
\text { grant } & \\
\text { - } & \text { Social charity } \\
\end{array}$ & Local or international \\
\hline $\begin{array}{l}\text { - Problem } \\
\text { originality }\end{array}$ & Quality control supervision & $\begin{array}{l}\text { - Write a strict guideline } \\
\text { before implementing a plan }\end{array}$ \\
\hline
\end{tabular}

\section{CONCLUSION}

Endangered tribe community must be revitalized in order to preserve the human civilization. When a civilization escaped from the true world none of us able to live it anymore. In revitalizing endangered tribe community many kinds of problems will emerge in the field, such as the difference of situation, area, social setting and cultural setting. Problems encountered in Minangkabau revitalization will be much different with the same work in other places like Africa, Europe, Australia and America. Moreover, the problems of specific work like revitalizing rumah gadang is having difference in economic revitalization and educational revitalization even though it is conducted in the same community.

\section{REFERENCES}

[1] Franzia, Elda, Piliang Yasraf Amir and Saidi Acep Iwan, Rumah gadang as a symbolic representation of Minangkabau ethnic identity. International Journal of Social Science and Humanity, 5 (1), 2015, 44-49.

[2] Francis, X Hezel, SJ. (2005). Cultural Loss; How Real is the Threat? Micronesian Counselor Journal at http://www.micsem.org/pubs/counselor/frames/cult_lossfr.htm. Accessed 03/11/2016.

[3] Janice C.Burns. at all. (2011). A Short Guide to Community Based Participatory Action Research. http//www.labor.ucla.edu/wp-content/uploads/2015/03/. Accessed in 03/18/2016.

[4] Partain, Robby. (2005). Signs of Church Revitalization. http//www.bluebonnetbaptis.org/ clientimages/ 21991/signsofchurchrevitalization. Accessed 03/14/2016.

[5] Andrew, Gulliford. (1992). Tribal Preservation: An Overview of Cultural Management: Reshaping Values and Tradition. Forum Journal, 6 (6), 1992.

[6] Gulliford, A. (1992). Tribal Preservation: An Overview of Cultural Management: Reshaping Values and Traditions.Forum Journal. Vol. 6. No.6. Preservationnation.org/forum/joinforumnow.html (accessed 03/11/2016)

[7] Woodward, K, Identity and Difference (London, Sage Publications, 2009)

[8] T.Kato. Matriliny and Migration; Evolving Minangkabau Tradition in Indonesia (Jakarta, Balai Pustaka, 2005) 
[9] Amir, MS. Adat Minangkabau; Pola dan Tujuan Hidup Orang Minang (Jakarta, Mutiara Sumber Widya, 2007)

[10] Lindawati, Alam dalam Persepsi Masyarakat Minangkabau (Padang, Andalas University, 2008)

[11] Sulastri, Asal usul Nama nama Tempat (daerah) di Minangkabau (Padang, Andalas University, 2006)

[12] Saanin, Hasanuddin, Bahasa Minangkabau (Padang, Universitas Andalas, 1980)

[13] Florian, Steinberg, Revitalization of Historic Inner-city Areas in Asia: The potential for urban renewal in Hanoi, Jakarta and Manila, (Asian Development Bank (ADB), 2008)

[14] J.M. Schilling, The Revitalization of Vacant Properties, http//www.usmayors.org/brownfields/library/ revitalization of vacant properties. Accessed in 03/11/2016 